\title{
Global Trade and Migration: Are Trade and Migration Substitutes or Complements? The Case of Nigeria
}

\author{
Taiwo V. Ojapinwa ${ }^{1}$ \& Bashir O. Kolawole ${ }^{2}$ \\ Department of Economics, Lagos State University, Ojo-Lagos, Nigeria ${ }^{1}$ \\ Department of Economics, Lagos State University, Ojo-Lagos, Nigeria ${ }^{2}$
}

\begin{abstract}
The paper examines the effects of trade as an alternative policy to manage migration in Nigeria. This study shed new light on the debate by bringing together papers that investigate the link between trade and factor mobility, particularly labour migration, from theoretical and empirical perspectives. This study conclude that imports and labour immigration are complements while some are substitute which are also the two strands of the theories which are based on the traditional and the modern theories.
\end{abstract}

Key Words: Globalisation, Trade, Migration, Substitutes, Complements, Nigeria

\section{Introduction}

Migration of people across national borders and continents is crucial for peace, stability and development at the national, sub-regional and regional levels. The potential for migrants to help transform their native countries has captured the imagination of national and local authorities; international institutions and the private sector. There is an emerging consensus that countries can cooperate to create triple wins -- for migrants, for their countries of origin and for the societies that receive them (Economic Commission for Africa (ECA), 2006). The Asian experience is well documented, and a number of recent studies point to the role of exports in growth accelerations. Jones and Olken (2008) identify growth accelerations, and show that these are associated with an average 13 percentage point increase in the share of trade in income (over a five-year period) as well as an acceleration of the rate of transfer of labour into manufacturing. Pattillo et al (2005) pointed to the association between growth accelerations and trade in Sub-Saharan Africa (see also Hausmann et al., 2005).

Economists have long argued that exposure to trade leads to increased competition and efficiency, resulting in greater specialization in production, and a wider and cheaper range of goods available to consumers (Dani, 1999 and Salimono, 1999). Likewise, mobility of productive factors (labour and capital) and the reduction of transaction costs are seen as essential to the smooth functioning of markets. In the case of trade, the General Agreements for Tariff and Trade (GATT)/World Trade Organisation (WTO) regime was constructed through a multilateral process with most favoured nation status (MFN), non-discrimination, and reciprocity as the organizing principles. In the case of international finance, exchange rate stability has been pursued unilaterally (by the U.S. during the early Bretton Woods period) and multilaterally through the IMF and World Bank. Both institutions have worked to solve problems of liquidity and adjustment as they arise. In each case, the international community seems to have accepted these goals/goods as indivisible, and herculean political efforts have been made to maintain openness and to solve free rider problems (Hollifield, 2006).

Several factors have played an important role in the recent expansion of trade, the growing integration of economies, and the increasing contribution of trade to development. These include the liberalization of tariffs and other barriers to trade; foreign direct investment through trade and investment negotiations and agreements; autonomous unilateral structural reforms; technological innovations in transport and communications; international solidarity through supportive measures (like trade preferences); and the strategic use of policies, experimentation and innovation.

The links between trade and factor movements are of increasing importance in a globalizing environment. The two classic papers in this literature are Mundell (1957) and Markusen (1983). While Mundell used the Heckscher-Ohlin framework to show that international trade and factor movement are substitutes, Markusen (1983) provided a strong challenge to the conventional wisdom of substitution between trade and factor movement. He presents five models in which he assumes free trade and identical endowments, and successively changes one of the other assumptions underlying the Heckscher-Ohlin model. He shows that eliminating barriers to factor movement results in complementarily (Markusen and Svensson 1985, Wong, 1986).

Based on the above, the main question this research study aims at answering is; does global trade and openness complements each other or they are substitute? This now bring up the objective of the study which is to investigate whether global trade and labour mobility are substitutes or complements in Nigeria. The second reason for this study is to also examine if trade liberalization is an option for reducing labour migration as traditional trade theory suggests. These aims will shed some light on the relationship between trade and 
migration for the considering theoretical and empirical literature review and draw conclusion for Nigeria. Although quite a lot of researches have been done regarding theoretical analysis, only a few studies deal with this question empirically.

The paper is structured as follows; the second section presents factors driving migration, its main characteristics of current migration and possible future trends. The standard theoretical framework of trade models and their conclusions regarding complementary or substitution links between trade and migration was presented. Empirical review of the literature is contained in section four and section five concluded.

\section{Factors Driving Migration \\ 2.1 Main characteristics of current migration and possible future trends}

Immigration into Nigeria has recently been increasing, as a result of the natural increase factor of population growth of the immigrant stock and an increase in the inflows of immigrants (IOM, 2009). The former is an indirect result of the age-sex selectivity factor of the migration process itself, which contributes to population growth, since immigrants are mostly in the reproductive 20-34 age group. Nonetheless, both the stock and flows of immigrants from less than 3 percent of the total population (International Organization for Migration (IOM, 2009) ). The majority of immigrants are labour migrants, who have diverse educational characteristics. Educated labour migrants, who are limited in number, occupy the top administrative, professional and service posts in the country. Such migrants increased in number once relative stability was established in the country in 1998 (Library of Congress, 2008).

There are fewer student immigrants than labour immigrants, with most of these students coming from Cameroon, Kenya and Sudan. Language barriers and related costs keep the number of student migrants low. Although significant in the 1990 s, refugee numbers have been declining and constitute only a small proportion of the overall immigrant stock $(0.8 \%)$ (NCFR, 2008). With the return to peace and democracy in Liberia and Sierra Leone, among others, and the official closure of the Oru Refugee Camp, a number of refugees have been repatriated. According to the National Commission for Refugees (NCFR) 2,345 people were voluntarily repatriated, 34 resettled in a third country and 10,401 returned (NCFR, 2008). The remaining refugees are offered the option of integration in the country under a joint project for the local integration of Liberian and Sierra Leonean refugees in Nigeria. The collaborating bodies are the Governments of Nigeria, Liberia and Sierra Leone, the Office of the United Nations High Commissioner for Refugees (UNHCR), the European Union and the Economic Community of West African States (ECOWAS).

Irregular migration to Nigeria is becoming an increasingly significant issue for the Government, particularly in the highly skilled sectors, such as the oil and gas industry (Vanguard, 2004). Many workers in these sectors overstay their visa or residence permit, while others manage to enter illegally. Although there is no reliable data on irregular migration, anecdotal evidence suggests that major countries of origin of irregular immigrants are the former war-torn ECOWAS Member States and Central African countries. Emigrants from Nigeria have been increasing at about the same rate as immigrants. The net migration rate in the last two decades has been negative, ranging between -0.1 and -0.21 (IOM, 2009). Although emigration and immigration levels hold each other almost in balance, the skill level of both types of migration differs considerably: more highly skilled persons leave the country than enter, thus creating skill shortages in sensitive sectors such as technology and health.

The education system still lacks the capacity to replace the skills that leave the country. In fact, the number of postgraduates trained at Nigerian universities has been declining, while the number of Nigerian students studying abroad has dramatically increased over the past few years. Nigerian students abroad account for 20 percent of all enrolments in Nigerian universities. With the potential negative implications for the country's human capital base, many of them remain abroad and become permanent immigrants in their country of destination (Mbanefoh, 2007).

Nigeria is a major economic bloc in Africa and offers a bigger market than most African countries put together. The unprecedented success story of the telecommunication business in Nigeria is an outstanding case study of successful entrepreneurship. The oil sector is the traditional magnet for foreign labour, although, the marginal economic growth in 2006-2007 has been attributed to non-oil sectors, in particular telecommunications $(28 \%)$ and wholesale and retail trade sectors (12\%) (IOM, 2009). The latter constitutes the country's main informal sector, which has traditionally been attracting low-skilled internal, as well as international, migrant labour. This increasing immigration rate implies that the Nigerian economy is attractive to labour migrants from the region and elsewhere and indeed grows partly due to labour migration.

The possible future trend in migration is that emigration is likely to continue to outpace immigration in the foreseeable future, that is, more and more people will emigrate, at least from among certain critical professional groups that have greater chances of marketing their skills outside the country. Although it might be too early to predict the impact of the economic crisis on migration patterns, however, it is likely that the economic crisis will cause only a small reduction in otherwise growing emigration flows in Nigeria since it is a 
global phenomenon. Remittances may also decline in the short term as migrants have less money to send home in times of hardship. Another important trend is that Nigerians are increasingly migrating to new destinations such as France, Ireland, the Netherlands and the United Arab Emirates. This is partly because of more restrictive policies in traditional countries of destination such as the United Kingdom. Most Nigerian migration is likely to remain intraregional.

\section{Theoretical Framework}

The last decade, as well as the prognosis for the future, is marked by the increased dynamism and impact of trade on development and the world economy. The sheer size, scale and growth of trade and its (potential) impact on development are the main features of global migration. This relationship between trade and factor movement starting with the contributions by Mundell (1957) and Markusen (1983) has been a subject for many researchers on a theoretical level. In this section an overview about different trade models and their implications for the relationship between trade and factor movement is given.

\subsection{Trade Theories}

In Ricardian Models (Markusen, 1983) trade occurs because of differences in production technology. At free trade each country exports the good for which it has an advantage in productivity. If there is also free movement of factors, there will be a factor inflow regarding the factor intensively used in the export sector. The reason is the higher factor reward in the sector with higher productivity. The initial comparative advantage is enhanced by the resulting endowment differences although this was not alluded to in the Ricardian model but it was emphazised that trade is augmented by factor movements. Transferred to the case of Nigeria and its considered migration partners, it seems likely that our natural resource endowment leads to increasing flow of immigration and inward capital flows while advances in production technology lead to emigration from Nigeria.

Meanwhile, according to the standard Heckscher-Ohlin model, trade occurs due to differences in factor endowment. Each country has a comparative advantage in that sector of production in which its abundant factor is intensively used. Trade leads to a convergence of goods prices which imply factor price equalization. It therefore follow that the incentives for factor movements are reduced. At the assumption of constant good prices changes in the endowment of the economy's scarce factor of production is followed by an expansion of the production in the import sector and a decrease in export sector production. Adding trade costs and/or costs for factor movement does not change the result of substitutability (Venables, 1999). Venables has analyzed the effects of trade liberalization regarding the movement of the general and the specific factors considering endowment differences and barriers to trade in goods. Apart from the general result of substitutability in some cases a complementary link between factor movements and trade is possible under certain conditions (Venables, 1999). Factor movements and trade are complements according to Markusen et al (1995). They argued that increasing returns to scale can be external or internal. External increasing returns to scale occur not in an individual firm but on an industry level (Markusen et al.,1995). Because every individual firm is small, the assumption of competitive markets still holds. With free trade and external increasing returns to scale both countries will specialize in order to gain from specialization. The reward of the factor intensively used in the respective sector will increase. Thus there is an incentive for factors, to move. Factor movement is followed by an increase in the output regarding both countries and thus an increase of trade

Internal increasing returns to scale are considered in the standard model of the "New Trade Theory". There are two countries with labour as the only factor of production within two sectors. One sector of production has constant returns to scale, the other one has internal increasing returns to scale. In the presence of monopolistic competition and internal increasing returns to scale the bigger economy will be a net exporter in the monopolistically-competitive sector (Krugman, 1995). The real factor reward will be higher in this region and this way there will be factor movement, making the two countries more unequal in endowment and thus increasing the basis for trade (Venables, 1999). In this case factor movements and trade are complements. This result is also supported by two other effects, first a "market access" effect. That is according to the "Linder Hypothesis" that enterprises tend to locate near their biggest markets in order to reduce transport costs (Krugman, 1995). Second a "cost of living" effect. The more the industry is concentrated, the lower is the goods prices and the cheaper are the costs of living. These effects support trade as well as factor movements.

According to trade models that are based on technological differences trade and factor movements are complements. The opposite is suggested by the standard trade model of Heckscher and Ohlin. This model suggests that with existing endowment differences trade and factor movements serve as substitutes which is hinged on its major assumption that factor labour and capital are though fully mobile between different industries but completely immobile between countries (Dwivedi, 2005). However, the results from extensions of the Heckscher-Ohlin model are ambiguous. Conclusions drawn from the specific factors model with endowment differences are also not clear. Here trade and factor movements may be substitutes or complements, depending on the factor in question, its mobility and consumption patterns. Models of the New Trade Theory, incorporating 
increasing returns to scale and monopolistic competition as well as other agglomeration forces suggest strongly that trade and factor movements are complementary.

\section{Empirical Literature}

Lopez and Schiff (1995) add four factors to the standard Heckscher-Ohlin model: labour skill levels (skilled or unskilled), international labour mobility, migration costs, and financing constraints. They examine two types of simulation. Case one applies to countries in the post-demographic transition stage, with a stable population. This includes countries of Eastern Europe and the former Soviet Union. Case two applies to countries with rapidly growing populations, such as Egypt, El Salvador, Mexico, and Morocco. In case one, the authors liberalization raises emigration of the unskilled (and has no effect on emigration of the skilled), while greater protection raises emigration of the skilled (and has no effect on emigration of the unskilled). That is, any change in trade policy raises total emigration, but trade liberalization improves the average skill level of the labour force and increased protection lowers it. In case two, they find that trade liberalization raises emigration of the unskilled and reduces emigration of the skilled. That is, the average skill level rises and the net effect on total emigration is ambiguous. The opposite occurs with increased protection. In both cases, the average skill level of the population falls when protection increases in the presence of international migration, high migration costs, and financing constraints. Under the same circumstances, the skill level rises under trade liberalization.

Hijzen and Wright (2005) in their study on migration, trade and wages adopts a GNP function approach in order to examine the impact of migrant labour on domestic factors of production in the United Kingdom during the period 1975-1996. They also examine the relationship between imports and migrants, which are two different facets of globalisation. They find that an increase in the number of unskilled migrants reduces the wages of unskilled domestic workers. They however suggest that the quantitative impact of this increase is small and that no discernible impact of migration is found for skilled native workers. The study therefore conclude that unskilled migrant workers and imports are substitutes in production, whilst skilled migrant workers and imports are complements.

Kohli (1999) models immigration of labour and trade in the framework of a production theory approach. In this case foreign labour and imports are viewed as an input to technology. The empirical part refers to the case of Switzerland. For a time period from 1950 to 1986 Kohli (1999) conclude that imports and labour immigration are complements.

Razin and Sadka (1999) in their study of international migration and international trade surveys key developments in the theory of international migration and international trade, and provides a few stylized facts. International migration, in many important cases, such as cross-country differences in productivity, was found to be a complement to international flows of commodities. In the presence of a productivity difference that is generated by an external economy effect of human capital, Razin and Sadka (1999) discover that physical capital has weak incentives to flow from developed to underdeveloped countries while pressures for international migration from poor to rich countries are strong. The modem welfare states typically redistribute income from the rich to the poor in a way which attracts poor migrants from the less developed countries. Since migration could impose a toll on the redistribution policy of the Developed Country it may benefit from the extension of foreign aid to the Less Developed Country if this aid serves to finance a subsidy to workers in the Less Developed Country, thereby containing migration.

Darity and Davis (2005) reviewed critically theories of growth and international trade from the perspective of understanding persistent inter-country and inter-regional income inequality. Three separate literatures were considered for the insights they offer about international disparity: Classical political economy, the North--South trade models, and the 'new' growth and trade theories that incorporate increasing returns and/or product differentiation. Classical antecedents of the more recent theories are identified, and contrasts are drawn between structuralist and neoclassical approaches to explaining the income gap between rich and poor nations. Richard Freeman (2009) contemplates the effects of world workforce doubling with the fall of the Soviet Union, China turn to the market and India liberalization. What effect has this globalization process had on wages worldwide? Though world wages were probably affected, Freeman emphasizes the fact that education and innovation are countervailing forces to wage repression. While he considers globalization as a positive especially in the long run, he suggests that the gains from the process can be reversed in the face of pandemics, climate change, ongoing terrorism, political insanity and capital markets failures. He ends with some good and bad scenarios for the future. Edward Leamer (2009) takes up the question of whether tariffs on imports raise wages as a counter-factual to whether open trade markets depress wages. He outlines four economic models to answer the question: Ricardo Model, Ricardo-Viner Model, Heckscher-Ohlin Model and the Stolper-Samuelson Theorem. He concludes that wages in capital-intensive industries generally are maintained; they remain low in labour-intensive industries; and they are subject to fluctuation in mixed industries. Sinn (2004) examines the effects of migration resulting from EU Eastern enlargement on the welfare states of Western Europe. Although migration is suggested to be good in principle, as he believe yields gains from trade and specialization for all 
countries involved, it does so only if it meets with flexible labour markets and if it is not artificially induced by gifts from the welfare state.

Using a dynamic computable general equilibrium model, Storm (2001) addressed the question: how open should a developing country's agriculture be to the world economy for the Indian economy? The simulation results show that the costs of "close" integration are large and unevenly distributed, irrespective of whether the agricultural reform is immediate or gradual. One form of "strategic" integration is operationalised that yields more desirable outcomes in terms of growth and income distribution. He also compares the effectiveness of the two policy regimes in coping with an adverse supply shock. Krugman (1993) similarly considered the equilibrium location of two industries in two countries. Both industries are imperfectly competitive and produce goods which are used in final consumption and as intermediates by firms in the same industry. Intermediate usage creates cost and demand linkages between firms and a tendency for agglomeration of each industry. When trade barriers are high the equilibrium involves division of both industries between both locations in order to meet the final demands of consumers. At lower trade barriers agglomeration forces dominate the equilibrium involves specialisation, with each industry concentrated in a single location. Economic integration may induce specialisation. Krugman studies the simple dynamics of the model and demonstrates that during adjustment processes a sizable proportion of the labour force may suffer lower real wages as relocation of industry occurs, although concludes that there are long run gains from integration.

In a study of the contribution to bilateral trade flows of expatriates from the OECD economies' living in less developed countries, Konecny (2009) suggests that the expatriates promote trade between the country of origin and country of residence. The expatriates' facilitation of trade is nonetheless said to be relatively weaker and works likely through different channels. Using a unique dataset on bilateral migration stocks, Konecny finds that a 10 percent increase in the size of an expatriate community leads to a 0.6 percent average increase in its OECD trade partner's imports against a 2.5 percent impact of immigrants in OECD countries. The import facilitating role of expatriate networks is centred in host countries with low institutional quality. In economies lying within the lowest third of the institutional quality distribution, a 10 percent increase in expatriate stock would lead to a 1.7 percent increase in imports into their country of origin. The figures therefore concludes that expatriates' role in exports are not statistically different from zero.

Mundra (2003) has a view on bilateral trade between the US and 47 trading partners for a time period from 1973 to 1980 . The empirical analysis is based on a semiparametric dynamic panel model. It becomes evident, that immigration promotes imports regarding finished and intermediate goods. Furthermore the trade enhancing effect was stronger the higher the proportion of skilled immigrants was. This could be due to a more efficient use of information, more entrepreneurship and maybe higher income that allow buying imported goods. Regarding exports a positive effect of immigration could only be shown for finished goods. Altogether the economic links between migration and trade are of complementary nature. Baldwin et al (1999) study the nature and the policy implication of changes in the global economy in relationship to the process of regional integration, conducted using the newest techniques of economic analysis. The principal message they drawn from these analytical and policy insights is that in a world characterised by trade distortions and nonlinearities, regional integration may or may not foster global integration, and may or may not advance regional or global convergence.

Most economists have taken a critical look at the current divide over immigration policies. For example, Faini, Melo and Zimmermann (1999) examine the substitutability between trade and migration, the impact of regional integration on the location of economic activity, the role of public goods provisions, and the political economy of migration. They shed new light on the debate by bringing together papers that investigate the link between trade and factor mobility, particularly labour migration, from theoretical and empirical perspectives.

Jarreau and Poncet (2009) consider the effect of export sophistication on economic performance using regional variations within a single country (China) over the period 1997-2007. They confirm Hausmann, Hwang and Rodrik (2007)'s prediction that regions that engage in the cost discovery process of developing sophisticated goods grasp greater gains from globalization and grow faster and find that these gains are limited to export activities undertaken by domestic entities. They also find out that direct gains do not appear to derive from foreign entities typically engaged in processing trade even though they are the main contributors to the global upgrading of China's exports. Jarreau and Poncet findings globally suggest that the expected gains from exporting higher productivity goods are not unconditional, they are greater for provinces already blessed by high incomes, better market centrality and higher trade performance and Foreign Direct Investment attractiveness. These features consistent with evidence of increasing returns to sophistication are unfortunately likely to contribute further to the current widening of spatial economic disparities across China.

Using tariffs as a measure of openness in their study on Openness, Inequality, and Poverty, Gourdon, Maystre and Jaime de Melo (2008) find evidence that the conditional effects of trade liberalization on inequality are correlated with relative factor endowments and that trade liberalization, measured by changes in tariff 
revenues, is associated with increases in inequality in countries well-endowed in highly skilled workers and capital or with workers that have very low education levels. Similar, though less robust, results are also obtained when decile data are used instead of the usual Gini coefficients. Taken together, the results are strongly supportive of the factor-proportions theory of trade and suggest that trade liberalization in poor countries where the share of the labour force with little education is high raises inequality. Simulation results also suggest that relatively small changes in inequality as measured by aggregate measures of inequality like the Gini coefficient are magnified when estimates are carried out using decile data.

The remarkable increase in trade flows and in migratory flows of highly educated people are two important features of globalization of the last decades. Iranzo and Peri (2009) extends a two-country model of inter- and intra-industry trade to a rich environment featuring technological differences, skill differences and the possibility of international labour mobility. They used the model to explain the patterns of trade and migration as countries remove barriers to trade and to labour mobility. They also parameterize the model to match the features of the Western and Eastern European members of the EU and analyze first the effects of the trade liberalization which occurred between 1989 and 2004, and then the gains and losses from migration which are expected to occur if legal barriers to labour mobility are substantially reduced. They find out that the lower barriers to migration would result in significant migration of skilled workers from Eastern European countries and therefore conclude that, this would not only benefit the migrants and most Western European workers but, via trade, it would also benefit the workers remaining in Eastern Europe.

Bowen \& $\mathrm{Wu}(2004)$ analyze changes in exports in relation to changes in total immigration and alternatively net immigration. The data include fourteen OECD countries for a period from 1980 until 2001. The results indicate a complementary relationship between immigration and trade. However, an interaction term of a guest worker dummy variable and immigration has a negative impact on trade. This impact outweighs the positive coefficient of immigration regarding net immigration but not regarding total immigration. Thus the result of complementarity is not without uncertainty for guest worker countries. Thus Bowen \& Wu (2004) presume an increased likelihood of a substitution link for countries that promoted guest worker programs. To sum up empirical contributions about migration and trade mainly point out that migration complements trade. This seems to be the case also for the links between foreign direct investment and trade. Only on a sectoral level Goldberg \& Klein (1999) finds substitution links for foreign direct investment depending on the analysed sector and the respective country.

\section{Conclusion}

In trade theory, the relationship between trade and migration depends on the assumptions made. The objective of this study is to test the effects of trade as an alternative policy to manage migration. This paper presented a theoretical and empirical review of the relationship between labour migration and trade. Subject of the analysis is on the one hand effects of labour migration on trade and on the other hand effects of trade intensity on labour migration.

The starting point of this analysis was the presentation of factors driving migration its main characteristics of current migration and possible future trends. Different suggestions of trade theories regarding the relationship between trade and factor movements were presented. This study shed new light on the debate by bringing together papers that investigate the link between trade and factor mobility, particularly labour migration, from theoretical and empirical perspectives. This study conclude that imports and labour immigration are complements while some are substitute which are also the two strands of the theories which are based on the traditional and the modern theories. The study therefore suggests that the increasing immigration rate implies that the Nigerian economy is attractive to labour migrants from the region and elsewhere and indeed grows partly due to labour migration. In our future endeavour we will investigate the link between trade and factor mobility in an empirical dimension.

\section{References}

[1]. Alexander, H. and Wright, P. W. (2005), Migration, Trade and Wages Working Papers from CEPII research centre.

[2]. Bowen, H. P. and Wu, J. P. (2004), Does it Matter Where Immigrants Work? Traded Goods, Non-traded Goods, and Sector Specific Employment. Bonn: Working Paper No. B16-2004Center for European Integration Studies.

[3]. Bruder, J. (2004), Are Trade and Migration Substitutes or Complements? - The Case of Germany, 1970-1998 University of Rostock.

[4]. Dani, R. (1999), The New Global Economic and the Developing Countries: Making Openness Work Baltimore, John Hopkin University Press.

[5]. Darity, W.A. and Davis, L.S. (2005), Growth, trade and uneven development Cambridge Journal of Economics, vol. 29, issue 1, pages $141-170$.

[6]. Dwivedi, D.N. (2005), Managerial Economics sixth Revised Edition, Vikas Publishing House PVT LTD.

[7]. Economic Commission for Africa, (ECA) (2006), International Migration and Development: Implications background document for the High Level Dialogue on Migration and Development United Nations General Assembly, 14-15 September 2006.

[8]. Faini, M. and Zimmermann, (1999) Migration in Cambridge Books from Cambridge University Press.

[9]. Freeman, R. B. and Leamer, E. (2009), Globalization and Living Standards Institute for Social Science Research, Working Paper Series from Institute for Social Science Research, UCLA 
[10]. Gourdon, M. and Melo, J. D. (2008), Openness, Inequality, and Poverty: Endowments Matter No 239, Development Working Papers from Centro Studi Luca d'Agliano, University of Milano.

[11]. Hausmann, R. and Rodrik, D (2003), Economic Development as Self- Discovery, Journal of Economic Growth, Vol. 72 , pp. 603-33.

[12]. Hausmann, R., Pritchett, L. and Rodrik, D. (2005), Growth Accelerations, Journal of Economic Growth, Vol. 10, No. 4, pp. $303-29$.

[13]. Hollifield, J. F. (2006), Trade, Migration and Economic Development The Risks and Rewards of Openness Ora Nixon Arnold Professor of International Political Economy Director, Tower Center ; Paper prepared for a conference on Migration, Trade and Development, Federal Reserve Bank of Dallas, Texas, October 2006.

[14]. International Organization for Migration (IOM) (2009) Migration in Nigeria a country profile 2009.

[15]. Jarreau and Poncet (2009), Export Sophistication and Economic Performance: Evidence from Chinese Provinces Working Papers from CEPII research centre.

[16]. Jones, B. and Olken, B. (2008), TheAnatomy of Start-Stop-Growth, Review of Economics and Statistics, Vol. 90 , No. 3, pp. $582-87$.

[17]. Kohli, U. (1999), Trade and Migration: A Production-Theory Approach. In Migration (p. 117-150). Cambridge: Cambridge University Press.

[18]. Konecny, (2009) Expatriates and Trade CERGE-EI Working Papers from The Center for Economic Research and Graduate Education - Economic Institute, Prague.

[19]. Krugman, P. and Venables, A.J. (1993), Intergration CEP Discussion Papers from Centre for Economic Performance, LSE.

[20]. Krugman, P. (1995), Increasing Returns, Imperfect Competition and the Positive Theory of International Trade. In Handbook of International Economics (p. 1243-1277). Elsevier Science.

[21]. Library of Congress (2008) Country Profile: Nigeria, 2008. Library of Congress, Federal Research Division.

[22]. Lopez, and Schiff, (1995), Migration and the skill composition of the labour force: the impact of trade liberalization in developing countries No 1493, Policy Research Working Paper Series from The World Bank.

[23]. Markusen, J. R. (1983), Factor Movements and Commodity Trade as Complements. American Economic Review, 47, 321 -335.

[24]. Mbanefoh, N. (2007), Brain Drain in the Health Sector in Africa: Examples from the University College Hospital (UCH), Ibadan.

[25]. Mundell, R. A. (1957), International Trade and Factor Mobility. American Economic Review, 47, 321-335.

[26]. Mundra, K. (2003), Immigration and International Trade: a Semiparametric Empirical

[27]. Patillo, C., Gupta, S. and Carey, K (2005), Sustaining Growth Accelerations and Pro-Poor Growth in Africa, IMF Working Paper 195, International Monetary Fund, Washington, DC.

[28]. Razin, A. and Sadka, E. (1999), International Migration and International Trade No 4230, NBER Working Papers from National Bureau of Economic Research, Inc.

[29]. Baldwin, R. Cohen, D. Sapir, A. and Venables, A.J. (1999), Market Integration, Regionalism and the Global Economy in Cambridge Books from Cambridge University Press.

[30]. Sinn, H.W. (2004), EU Enlargement, Migration and the New Constitution No 1367, CESifo Working Paper Series from CESifo Group Munich.

[31]. Salimono, A. (1999), Globalization and Challenges. A Paper Presented at the International Summit on Globalization as problem of development in Harana Cuba. Jan.18-22.

[32]. Storm, S (2001), The Desirable Form of Openness for Indian Agriculture Cambridge Journal of Economics, 2001, vol. 25, issue 2, pages 185-207.

[33]. Venables, A. J. (1999), Trade Liberalization and Factor Mobility. In Migration (p.23-48). Cambridge: Cambridge University Press.

[34]. Wong, K.-Y. (1986), Are International Trade and Factor Mobility Substitutes. Journal of International Economics, 21, 25-43.

\section{APPENDIX 1}

Table 12: Population and migration characteristics of Nigeria: 1990, 2000 and 2005

\begin{tabular}{|l|l|l|l|l|}
\hline & $\mathbf{1 9 9 0}$ & $\mathbf{2 0 0 0}$ & $\mathbf{2 0 0 5}$ & $\mathbf{2 0 1 0}$ \\
\hline Estimated total population at mid-year ('000) & 97,338 & 124,842 & 140,879 & 158,259 \\
\hline Estimate of international migrants at mid-year ('000) & 447 & 751 & 972 & 1,127 \\
\hline International migrants as \% of total population & 0.5 & 0.6 & 0.7 & 0.7 \\
\hline & $\mathbf{1 9 9 5 - 2 0 0 0}$ & $\mathbf{2 0 0 0 - 2 0 0 5}$ & $\mathbf{2 0 0 5 - 2 0 1 0}$ & -60 \\
\hline Net number of international migrants ('000) & -19 & -34 & -0.3 & 0.4 \\
\hline Net migration rate (per 1,000 people) & -0.2 & & \\
\hline
\end{tabular}

Source: UNPD, 2008 and 2009.

Table 15: Nigeria foreign trade, 2000-2007 (million naira)

\begin{tabular}{|l|l|l|l|l|l|l|l|l|}
\hline & $\mathbf{2 0 0 0}$ & $\mathbf{2 0 0 1}$ & $\mathbf{2 0 0 2}$ & $\mathbf{2 0 0 3}$ & $\mathbf{2 0 0 4}$ & $\mathbf{2 0 0 5}$ & $\mathbf{2 0 0 6}$ & $\mathbf{2 0 0 7}$ \\
\hline Import (cif) & $\mathbf{5 9 1 , 3 2 6}$ & $\mathbf{8 8 5 , 1 1 4}$ & $\mathbf{1 , 0 5 4 , 0 7 6}$ & $1,923,099$ & $\mathbf{1 , 5 7 5 , 5 6 4}$ & $\mathbf{1 , 7 7 9 , 6 0 2}$ & $\mathbf{2 , 9 2 2 , 2 4 9}$ & $\mathbf{4 , 1 2 7 , 6 9 0}$ \\
\hline Export(fob ) & $\mathbf{2 , 7 5 2 , 0 5 8}$ & $\mathbf{2 , 0 0 7 , 1 2 7}$ & $\mathbf{2 , 1 6 7 , 4 1 2}$ & $\mathbf{3 , 1 0 9 , 2 8 8}$ & $\mathbf{5 , 1 2 9 , 0 2 6}$ & $\mathbf{6 , 6 2 1 , 3 0 4}$ & $\mathbf{7 , 5 5 5 , 1 4 1}$ & $\mathbf{6 , 8 8 1 , 5 0 1}$ \\
\hline Balance & $\mathbf{2 , 1 6 0 , 7 3 2}$ & $\mathbf{1 , 1 2 2 , 0 1 3}$ & $\mathbf{1 , 1 1 3 , 3 3 7}$ & $\mathbf{1 , 1 8 6 , 1 9 0}$ & $\mathbf{3 , 5 5 3 , 4 6 2}$ & $\mathbf{4 , 8 4 1 , 7 0 2}$ & $\mathbf{4 , 6 3 2 , 8 9 3}$ & $\mathbf{2 , 7 5 3 , 8 1 1}$ \\
\hline
\end{tabular}

Source: NBS, 2008. 